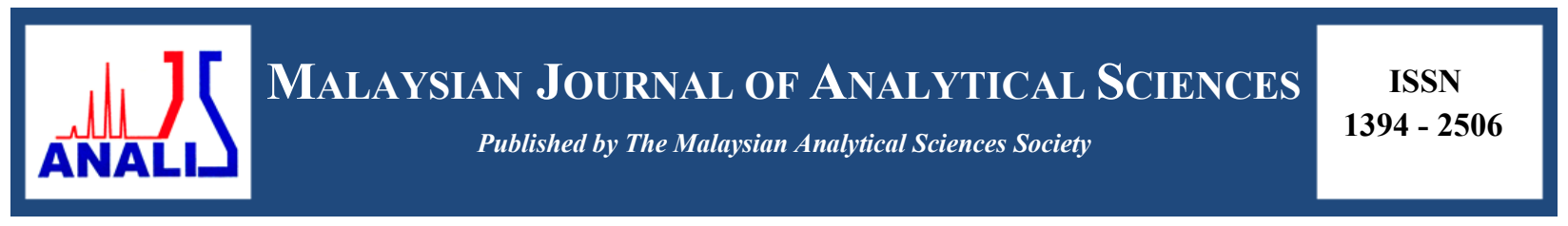

\title{
ISOTHERMAL MODELLING BASED EXPERIMENTAL STUDY OF DISSOLVED HYDROGEN SULFIDE ADSORPTION FROM WASTE WATER USING EGGSHELL BASED ACTIVATED CARBON
}

\author{
(Model Isoterma Berdasarkan Kajian Penjerapan Hidrogen Sulfida Terlarut daripada Air Sisa \\ Menggunakan Karbon yang Diaktifkan Berasaskan Kulit Telur) \\ Omar Abed Habeeb ${ }^{1}$, Ramesh Kanthasamy ${ }^{*}$, Gomaa Abdelgawad Mohammed Ali ${ }^{2,3}$, Rosli Mohd. Yunus ${ }^{1}$ \\ ${ }^{I}$ Faculty of Chemical Engineering \& Natural Resources Engineering \\ ${ }^{2}$ Faculty of Industrial Sciences and Technology \\ Universiti Malaysia Pahang, Gambang, 26300 Kuantan, Pahang, Malaysia \\ ${ }^{3}$ Chemistry Department, Faculty of Science, \\ Al-Azhar University, Assiut, 71524, Egypt \\ *Corresponding author: ramesh@ump.edu.my
}

Received: 8 June 2016; Accepted: 19 January 2017

\begin{abstract}
This paper reports on the experimental work using batch process conducted to determine the adsorption capacity of dissolved hydrogen sulfide in the synthetic wastewater onto the activated carbon which is derived from the eggshell. Fourier Transform Infrared Spectroscopy (FTIR), Energy-Dispersive X-ray Spectroscopy (EDX), Scanning Electron Microscopy (SEM), and particle size distribution have been used to characterize the prepared material. The raw materials of chicken eggshell are adopted to retrieve the carbon content which is then activated using $\mathrm{KOH}$ as the activation agent. The examined concentration of dissolved hydrogen sulfide is ranging from 100 to $500 \mathrm{ppm}$. The maximum adsorption capacity of the dissolved $\mathrm{H}_{2} \mathrm{~S}$ onto the activated carbon is $289.3 \mathrm{mg} / \mathrm{g}$ and the equilibrium time is 6 hours. The examined $\mathrm{pH}$ value in this study is ranging from 4.5 to 5.5. The two well-known equilibrium adsorption isotherm models, i.e. the Langmuir and the Freundlich models, are employed. It is found that the adsorption isotherm capacity agrees very well to the Freundlich isotherm model. This paper attempts to show the difficulties of converting $\mathrm{CaCO}_{3}$ to carbon due to the fact that the raw material contains higher calcium (Ca) content instead of carbon. It is concluded that the carbon derived from the chickens' eggshells is very beneficial for treatment of dissolved $\mathrm{H}_{2} \mathrm{~S}$ in waste water.
\end{abstract}

Keywords: adsorption, hydrogen sulfide, chicken eggshells, activated carbon, isotherm

\begin{abstract}
Abstrak
Kajian ini melaporkan mengenai kerja eksperimen menggunakan proses kelompok yang dijalankan untuk menentukan kapasiti penjerapan hidrogen sulfida terlarut dalam air sisa sintetik ke dalam karbon yang diaktifkan dihasilkan daripada kulit telur. Spektroskopi Inframerah Fourier (FTIR), Spektroskopi X-ray Tenaga Serakan (EDX), Mikroskop Imbasan Elektron (SEM), dan taburan saiz zarah telah digunakan untuk mencirikan bahan yang disediakan. Kulit telur ayam sebagai bahan mentah telah digunakan untuk mendapatkan semula kandungan karbon yang kemudiannya diaktifkan dengan menggunakan $\mathrm{KOH}$ sebagai agen pengaktifan. Julat kepekatan hidrogen sulfida yang diperiksa adalah di antara 100 hingga 500 ppm. Kapasiti penjerapan maksimum $\mathrm{H}_{2} \mathrm{~S}$ terlarut ke dalam karbon diaktifkan adalah $289.3 \mathrm{mg} / \mathrm{g}$ dan masa keseimbangan selama 6 jam. Julat nilai $\mathrm{pH}$ yang diperiksa dalam kajian ini di antara 4.5 hingga 5.5. Kedua-dua model penjerapan isoterma keseimbangan terkenal seperti model Freundlich dan Langmuir telah dilaksanakan. Kapasiti penjerapan isoterma didapati selari dengan model isoterma Langmuir. Kajian ini cuba menunjukkan kesukaran untuk menukar $\mathrm{CaCO}_{3}$ kepada karbon disebabkan oleh bahan mentah
\end{abstract}




\section{Habeeb et al: ISOTHERMAL MODELLING BASED EXPERIMENTAL STUDY OF DISSOLVED HYDROGEN SULFIDE ADSORPTION FROM WASTE WATER USING EGGSHELL BASED ACTIVATED CARBON}

mengandungi kandungan kalsium (Ca) yang tinggi dan bukannya karbon. Ini dapat disimpulkan bahawa karbon yang diperolehi daripada kulit telur ayam adalah sangat bermanfaat untuk rawatan $\mathrm{H}_{2} \mathrm{~S}$ terlarut dalam air sisa.

Kata Kunci: penjerapan, hidrogen sulfida, kulit telur ayam, karbon diaktifkan, isoterma

\section{Introduction}

Hydrogen sulfide $\left(\mathrm{H}_{2} \mathrm{~S}\right)$ is a very toxic, corrosive and flammable gas. It is a colorless gas, best known for its strong smell, much like the strong nauseating smell of rotten eggs. The $\mathrm{H}_{2} \mathrm{~S}$ is volatile in water and soluble in some polar organic solvents [1]. It is also a reducing agent and oxidizes easily when the conditions are right and corrodes metals and even concrete. For example, $\mathrm{H}_{2} \mathrm{~S}$ will oxidize gradually to elemental sulfur and over time oxidize to sulfuric acid and eventually damage the sewer [2]. Under specific conditions such as at a low concentration (1.36 $\mathrm{mg} / \mathrm{L}) \mathrm{pH}$ between 3 to 5 and immersion time of more than two hours, $\mathrm{H}_{2} \mathrm{~S}$ has been found to have an inhibiting effect on iron corrosion [3,4]. Moreover, $\mathrm{H}_{2} \mathrm{~S}$ is also a harmful and putrid gaseous compound. It can create health problems, like coma, irritated eyes, and respiratory system irritation. Furthermore, the human nose can detect $\mathrm{H}_{2} \mathrm{~S}$ at concentrations as low as 0.5 part-per-billion-volume (ppbv) [5]. Therefore, excess exposure to $\mathrm{H}_{2} \mathrm{~S}$ can cause both chronic and acute ramifications [6]. Surprisingly, the allowable limit of $\mathrm{H}_{2} \mathrm{~S}$ in drinking water is not specified by the World Health Organization (WHO) [7]. Most of the sulfide found in water may be expected to exist as molecular $\mathrm{H}_{2} \mathrm{~S}$ at $\mathrm{pH}$ less than 4 [8]. Bisulfide and sulfide ions can be found when $\mathrm{H}_{2} \mathrm{~S}$ is dissolved in water as per the following reaction:

$$
\begin{aligned}
& \mathrm{H}_{2} \mathrm{~S}_{(\mathrm{g})} \leftrightarrow \mathrm{H}_{2} \mathrm{~S}_{(\mathrm{aq})} \\
& \mathrm{H}_{2} \mathrm{~S}_{(\mathrm{aq})} \leftrightarrow \mathrm{H}^{+}+\mathrm{HS}^{-} \\
& \mathrm{HS}^{-} \leftrightarrow \mathrm{H}^{+}+\mathrm{S}^{2-}
\end{aligned}
$$

Reaction 2 (reverse direction) occurs at $\mathrm{pH}<4.5$ [9] and reaction 3 (forward direction) happens at $\mathrm{pH} \geq 9$ [10]. In a natural environment, acid rain is precipitated through the oxidation of $\mathrm{H}_{2} \mathrm{~S}$ to sulfuric acid. $\mathrm{H}_{2} \mathrm{~S}$ dissolves easily in water $(4-6 \mathrm{~g} / \mathrm{L})$ and it is poisonous to almost all types of life forms [11]. Owing to the above reasons, various agencies have been consistently developing solutions to remove $\mathrm{H}_{2} \mathrm{~S}$. It could be removed in three different ways such as adsorption, oxidation, and scrubbing. Recently, there is a renewed interest in using adsorption process as an effective method to remove the pollutant e.g. $\mathrm{H}_{2} \mathrm{~S}$ from wastewater. Adsorption is a physio-chemical technique, involving mass transfer between the liquid and the solid phase [12]. A considerable amount of literatures detailing on the removal of $\mathrm{H}_{2} \mathrm{~S}$ have been published [13-15]. These studies have reported that the adsorption rate of $\mathrm{H}_{2} \mathrm{~S}$ is affected by many factors such as surface area of adsorbent, pore size, moisture content, $\mathrm{pH}$, and surface chemistry (oxygen containing functionalities). The experimental and simulation study detailing on $\mathrm{H}_{2} \mathrm{~S}$ adsorption on impregnated activated carbon under an anaerobic condition has been carried out by Xiao et al. [13]. They have applied a sodium carbonate impregnated activated carbon as the adsorbent for low concentration $\mathrm{H}_{2} \mathrm{~S}$ in nitrogen under the anaerobic condition in a fixed bed [13]. Moreover, sludge-derived $\mathrm{H}_{2} \mathrm{~S}$ adsorbents have received considerable attentions from the galvanizing industry [14].

Other study has been conducted by Guo et al. [15], whereby they have studied activated carbons derived from oilpalm shell as an adsorption of $\mathrm{H}_{2} \mathrm{~S}$ [15]. In addition, study on ferric and alum water treatment residuals has been conducted by Wang and Pei [16]. Possible materials to be used as adsorbents of $\mathrm{H}_{2} \mathrm{~S}$ such as Fine Rubber Particle Media (FRPM) and crushed oyster shell have been tested by Wang [17] and Asaoka [18], respectively. Recently, the low-cost carbon-based materials such as agricultural wastes have been used as pollutant adsorbent such as rice husks [19], banana and orange peels [20], coconut shell [21], macadamia nut shells [22], fibers of oil palm empty fruit bunches [23], rice straw [24]. Several studies have documented that activated carbon has been widely used as an adsorbent for achieving high water purification. So far, very little attention has been paid to remove $\mathrm{H}_{2} \mathrm{~S}$ from wastewater in liquid phase.

Therefore, this paper addresses on the use of eggshells as the source of activated carbon to adsorb dissolved $\mathrm{H}_{2} \mathrm{~S}$ as liquid form out of wastewaters. It is important to note that eggshells are abundant and environmental friendly [25]. In this paper, our objective is to assess the effectiveness of activated carbon derived from eggshell waste as an adsorbent of dissolved $\mathrm{H}_{2} \mathrm{~S}$ from waste water. Also, we aim to characterize this adsorbent and find the suitable isotherm adsorption model to be fitted with this adsorption process. 


\section{Preparation of activated carbon}

\section{Materials and Methods}

In this study, the activated carbon derived from eggshells has been used as an adsorbent of $\mathrm{H}_{2} \mathrm{~S}$ appeared in the petroleum refinery synthetic waste water. Firstly, the eggshells (around 100 pieces) were collected from restaurants around Kajang, Selangor, Malaysia. A sample of the eggshells was then carefully rinsed several times with deionized water and acidic solvent to remove impurities and pollutants. After that, the sample was gradually dried under $105^{\circ} \mathrm{C}$ for eight hours. Then the dried eggshell was grinded into powder form. The powder $(10 \mathrm{~g})$ was placed in a furnace and gradually heated up to $700{ }^{\circ} \mathrm{C}$ [26], at constant heating rate of $10{ }^{\circ} \mathrm{C} / \mathrm{min}$ with nitrogen $\left(\mathrm{N}_{2}\right)$ flow rate of $150 \mathrm{~mL} / \mathrm{min}$. Then the result product was soaked in concentrated solution of $\mathrm{KOH}$ for 24 hours. After that, it is filtered and dried under $105^{\circ} \mathrm{C}$. Finally, the activation process is done in a horizontal tubular furnace at temperature of $750^{\circ} \mathrm{C}$, which is subjected to constant heating rate of $10^{\circ} \mathrm{C} / \mathrm{min}$ with $\mathrm{N}_{2}$ flow rate of $150 \mathrm{~mL} / \mathrm{min}$. The prepared material was coded as ACES.

\section{Characterization of activated carbon}

In this study, the $\mathrm{pH}$ value of the carbon surface was measured by taking a sample of $0.4 \mathrm{~g}$ of dry carbon powder added to $20 \mathrm{~mL}$ of water and the suspension was stirred overnight to reach equilibrium. Then, the $\mathrm{pH}$ value of the suspension was measured. Moreover, the surface morphology of the sample was examined using a Scanning Electron Microscope (SEM). Elemental analysis on the chemical composition of the sample was conducted using the energy-dispersive X-ray spectroscopy (EDX). The particle size distribution was also measured. The Fourier Transform Infrared Spectroscopy (FTIR) analysis has been used for the examination of functional groups on the surface of adsorbent.

\section{Hydrogen sulfide solution}

In this study, the synthetic waste water was prepared according to the procedure reported by Asaoka et al. [18]. A portion of $\mathrm{Na}_{2} \mathrm{~S} .9 \mathrm{H}_{2} \mathrm{O}$ was dissolved in $500 \mathrm{~mL}$ solution of $0.01 \mathrm{M} \mathrm{KCl}$ purged with $\mathrm{N}_{2}$ gas. Thereafter, the pH of the solution was adjusted to $4.5-5.5$ using $0.2 \mathrm{M} \mathrm{HCl}$ [18]. The concentration of dissolved $\mathrm{H}_{2} \mathrm{~S}$ in water is $4-6$ $\mathrm{g} / \mathrm{L}$ [11]. All forms of $\mathrm{H}_{2} \mathrm{~S}$ are harmful to organisms, and they can exist in a solution in three forms, i.e. hydrogen sulfide $\left(\mathrm{H}_{2} \mathrm{~S}\right)$, bisulfide $\left(\mathrm{HS}^{-}\right)$and sulfide $\left(\mathrm{S}^{2-}\right)$ [27].

\section{Batch equilibrium studies}

The adsorption capacity of the ACES has been carefully studied by examining its ability in removing $\mathrm{H}_{2} \mathrm{~S}$ from synthetic wastewater. The pollutant concentration was initially measured. The $\mathrm{pH}$ of the solution was controlled to $4.5-5.5$ using $\mathrm{NaOH}$ and $\mathrm{HCl}$. The experiments of the adsorption process of $\mathrm{H}_{2} \mathrm{~S}$ were conducted using a batch mode process. For each experiment, the adsorption was carried out using $0.1 \mathrm{~g}$ of adsorbent after degassing at $105^{\circ} \mathrm{C}$ for 24 hours in the oven. The solution was rotated at $160 \mathrm{rpm}$ with an electric shaker for 9 hours to test their adsorption capacities. Upon the filtration of the suspensions, the initial and final concentration were measured. The adsorption capacity of the pollutants was calculated using equation 4 below:

$$
q_{e}=\frac{\left(C_{0}-C_{e}\right) V}{m}
$$

where $V$ is the solution volume $(L), m$ is the adsorbent amount $(g), C_{o}$ and $C_{e}$ are the initial and final concentrations of the pollutants, and $\left(q_{e}\right)$ is adsorption capacity in $\mathrm{mg} / \mathrm{g}$. All adsorption experiments were repeated and the maximum deviation was within 5\%. All the measurements were done at fume hood as $\mathrm{H}_{2} \mathrm{~S}$ is a very dangerous gas. The adsorbent sample yield can be calculated using the following equation 5 below:

$$
\text { Yield }(\%)=\frac{W_{c}}{W_{o}} \times 100 \%
$$

where $W_{c}$ and $W_{o}$ are the dry weight of the final sample $(g)$ and the dry weight of precursor $(g)$, respectively. The equilibrium data were then fitted using the adsorption isotherm models, namely the Langmuir and the Freundlich models. 


\section{Habeeb et al: ISOTHERMAL MODELLING BASED EXPERIMENTAL STUDY OF DISSOLVED HYDROGEN SULFIDE ADSORPTION FROM WASTE WATER USING EGGSHELL BASED ACTIVATED CARBON}

\section{Adsorption isotherm models}

The adsorption isotherm models explained the connection between the amounts of adsorbate adsorbed per unit mass of adsorbent (equilibrium adsorption capacity, $q_{e}$ ) at constant temperature and adsorbate's concentration at equilibrium conditions $\left(C_{e}\right)$. Langmuir and Freundlich models are considered the well-known equilibrium adsorption isotherm models, and they were employed in the current study. Langmuir isotherm assumes monolayer adsorption onto a surface containing a finite number of adsorption sites of uniform strategies of adsorption with no transmigration of adsorbate in the plane of surface [28]. The linear form of Langmuir's isotherm model is given by the following equation 6 below:

$$
\frac{C_{e}}{q_{e}}=\frac{1}{Q_{\max } K_{l}}+\left(\frac{1}{Q_{\max }}\right) C_{e}
$$

where $C_{e}$ is the equilibrium concentration of the adsorbate $\left(\mathrm{H}_{2} \mathrm{~S}\right)(\mathrm{mg} / \mathrm{L}), q_{e}$ is the amount of adsorbate adsorbed per unit mass of adsorbent (mg/g), and parameters such as $Q_{\max }$ and $b$ are Langmuir constants related to monolayer adsorption capacity and affinity of adsorbent towards adsorbate, respectively. The essential characteristics of the Langmuir isotherm can be expressed in terms of a dimensionless equilibrium parameter $\left(R_{L}\right)$, which is defined by:

$$
R_{L}=\frac{1}{1+b C_{0}}
$$

where $C_{\mathrm{o}}$ is the $\mathrm{H}_{2} \mathrm{~S}$ initial concentration (in $\mathrm{mg} / \mathrm{L}$ ). The value of $R_{L}$ indicates the type of the isotherm to be either unfavorable, linear, favorable, or irreversible as reported in Table 1.

Table 1. The range values of $R_{L}$

\begin{tabular}{ll}
\hline Value of $\mathbf{R}_{\mathbf{L}}$ & Type of isotherm \\
\hline $\mathrm{R}_{\mathrm{L}}>1$ & Unfavorable \\
$\mathrm{R}_{\mathrm{L}}=1$ & Linear \\
$0<\mathrm{R}_{\mathrm{L}}<1$ & Favorable \\
$\mathrm{R}_{\mathrm{L}}=0$ & Irreversible \\
\hline
\end{tabular}

The Freundlich isotherm is another adsorption isotherm model which assumes heterogeneous surface energies, in which the energy term in Langmuir equation varies as a function of the surface coverage [29]. The correlation coefficients $\left(R^{2}\right)$ is used to judge the applicability of an isotherm model. The well-known logarithmic form of the Freundlich model is given by the following equation 8 below:

$$
\log q_{e}=\log K_{F}+\frac{1}{n} \log C_{e}
$$

where $q_{e}$ is the adsorption capacity at equilibrium $(\mathrm{mg} / \mathrm{g}), C_{e}$ is the equilibrium concentration of the adsorbate $\left(\mathrm{H}_{2} \mathrm{~S}\right)$ and $K_{F}$ and $\mathrm{n}$ are Freundlich constants.

\section{Adsorption kinetic models}

Normally, the pseudo-first-order, pseudo-second-order and other kinetic models are used to simulate adsorption kinetics and determine the reaction rates. The mathematical relations of pseudo-first-order and pseudo-second-order are as given in equations 9 and 10 , respectively [30,31]:

$$
\begin{aligned}
& \log \left(q_{e}-q_{t}\right)=\log q_{e}-\frac{k_{1}}{2.303} t \\
& \frac{1}{q_{t}}=\frac{1}{k_{2} q_{e}^{2}}+\frac{1}{q_{e}} t
\end{aligned}
$$


where $\mathrm{q}_{\mathrm{e}}$ and $\mathrm{q}_{\mathrm{t}}$ are the $\mathrm{H}_{2} \mathrm{~S}$ adsorbed $(\mathrm{mg} / \mathrm{g})$ at equilibrium and at time $\mathrm{t}(\mathrm{h})$, respectively. $\mathrm{k}_{1}\left(\mathrm{~h}^{-1}\right)$ and $\mathrm{k}_{2}(\mathrm{~g} / \mathrm{mg} \mathrm{h})$ are the rate constants for pseudo-first-order and pseudo-second-order, respectively.

\section{Textural characterization of prepared activated carbon}

\section{Results and Discussion}

Table 2 shows the composition of eggshell after the carbonization process. As seen, the prepared materials showed a high of carbon and oxygen of $30.36 \%$ and $50.27 \%$, respectively. Indicating the carbon structure of the prepared material. Calcium is lower as compared to carbon and oxygen, which is could be attributed to remaining component of eggshells. Furthermore, the morphology of the adsorbent surface was tested using SEM, it is interesting to find that the extural structure of the ACES particles has porous structure with fine pores and cracks as shown in Figure 1. The porous materials is preferable for the adsorption processes as it will discussed in the coming sections.

Table 2. The elemental composition of ACES

\begin{tabular}{lcc}
\hline Element & Weight \% & Weight Error $( \pm)$ \\
\hline Carbon $(\mathrm{C})$ & 30.36 & 0.47 \\
Oxygen $(\mathrm{O})$ & 50.27 & 0.86 \\
Molybdenum $(\mathrm{Mo})$ & 6.16 & 0.31 \\
Calcium $(\mathrm{Ca})$ & 12.48 & 0.31 \\
Potassium $(\mathrm{K})$ & 0.40 & 0.07 \\
Magnesium $(\mathrm{Mg})$ & 0.33 & 0.07 \\
Total & 100.00 & \\
\hline
\end{tabular}

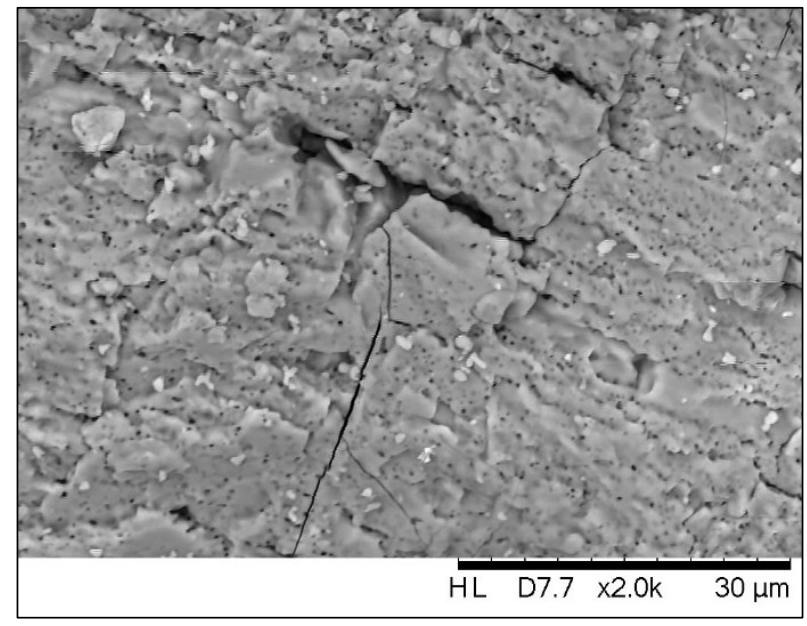

Figure 1. SEM image of ACES

Figure 2 shows the particle size distribution of adsorbent and Figure 3 shows another analytical test which is reporting on the FTIR structure of ACES particle. From Figure 3, it is obvious that the FTIR spectrum of ACES reveals three peaks. Each peak represents different functional group which might play an important role in the adsorption process. This corresponds to the presence of $\mathrm{OH}$ (hydroxyl), $\mathrm{C}=\mathrm{C}$ (alkynes), and $\mathrm{C}-\mathrm{O}$ (anhydrides) derivatives. Therefore, these surface functional groups could enhance the adsorption capacity of acidic pollutant (dissolved $\mathrm{H}_{2} \mathrm{~S}$ ) in the waste water. Apart from that, at lower $\mathrm{pH}$, the $\mathrm{H}^{+}$component which is high in concentration 
Habeeb et al: ISOTHERMAL MODELLING BASED EXPERIMENTAL STUDY OF DISSOLVED

HYDROGEN SULFIDE ADSORPTION FROM WASTE WATER USING EGGSHELL BASED

ACTIVATED CARBON

may increase the positively charged $\mathrm{CaOH}^{2+}$. It has been indicated that some reactions might occur during the adsorption process on the surface of adsorbent. Hence, reaction outlined in equation (11) might happen due to the oxygen content supporting the carbonization process of raw material. However, the dissociation of calcium oxide in water outlined in equation (12) forms calcium hydroxide $\left(\mathrm{Ca}(\mathrm{OH})_{2}\right)$ on the surface of ACES adsorbent which might help the adsorbent to attract via active site the acidic pollutant such as $\mathrm{H}_{2} \mathrm{~S}$. Moreover, in equation (13) the $\mathrm{OH}^{-}$ from $\mathrm{Ca}(\mathrm{OH})_{2}$ reacts with $\mathrm{H}_{2} \mathrm{~S}$ to form $\mathrm{Ca}(\mathrm{HS})_{2}$ which is then converted to element sulfur as demonstrated in equation (14).

$$
\begin{aligned}
& \mathrm{CaCO}_{3} \rightarrow \mathrm{CaO}+\mathrm{CO}_{2} \\
& \mathrm{CaO}+\mathrm{H}_{2} \mathrm{O} \rightarrow \mathrm{Ca}(\mathrm{OH})_{2} \\
& \mathrm{Ca}(\mathrm{OH})_{2}+\mathrm{H}_{2} \mathrm{~S} \rightarrow \mathrm{Ca}(\mathrm{HS})_{2}+2 \mathrm{H}_{2} \mathrm{O} \\
& \mathrm{Ca}(\mathrm{HS})_{2}+\mathrm{O}_{2} \rightarrow \mathrm{Ca}(\mathrm{OH})_{2}+2 \mathrm{~S}
\end{aligned}
$$

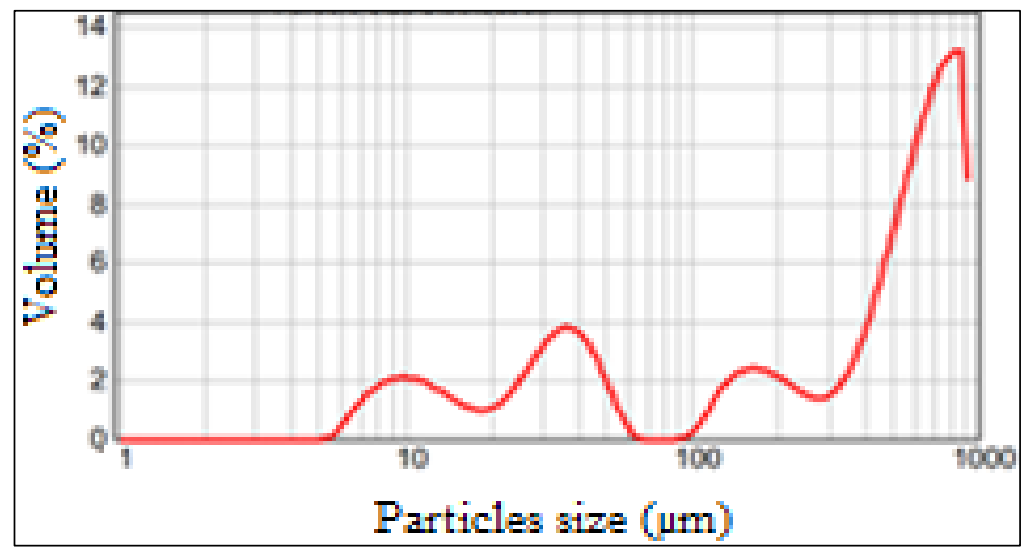

Figure 2. The particle size activated carbon derived from eggshell

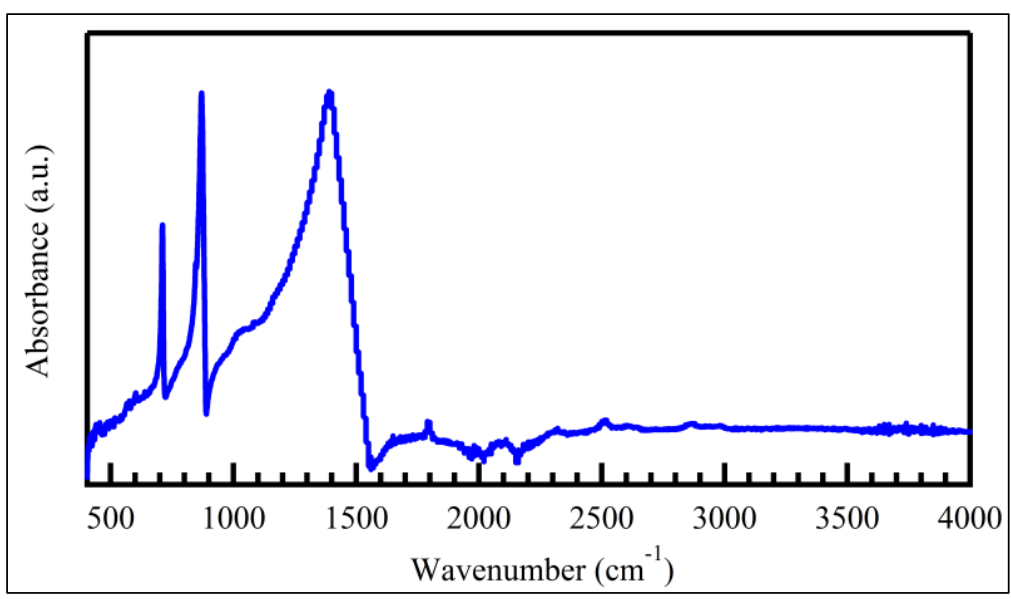

Figure 3. FTIR spectra of the ACES 
Effect of contact time and initial hydrogen sulfide concentration on adsorption equilibrium

A series of contact time experiments for $\mathrm{H}_{2} \mathrm{~S}$ have been carried out at different initial concentrations $(100-500$ $\mathrm{mg} / \mathrm{L}$ ) and at temperature of $30{ }^{\circ} \mathrm{C}$. Figure 4 shows that the equilibrium time of 6 hours is required for $\mathrm{H}_{2} \mathrm{~S}$ removal with the higher range of initial concentration $(300-500 \mathrm{mg} / \mathrm{L})$. However, with lower initial concentrations range $(100-200 \mathrm{mg} / \mathrm{L})$, a equilibrium time of 5 hours is required. As can be clearly seen from Figure 4, the amount of adsorbed $\mathrm{H}_{2} \mathrm{~S}$ onto the modified adsorbent (ACES) increases with time and it reaches an asymptote as time progresses. The results reveals that the $\mathrm{H}_{2} \mathrm{~S}$ adsorption rate is high at the initial stage of the contact period, and it becomes slower thereafter. This phenomenon happens due to the activity of functional group on the surface of adsorbent. It has been noted that vacant surface sites are vastly available for adsorption during the initial stage. However, as time elapses, it is difficult to occupy the remaining vacant surface sites due to the repulsive forces between the solute molecules on the solid and bulk phases. The results of this study indicate that the initial concentration has an important role in the adsorption capacity. Similarly, Choo et al. has found that higher concentration yields enhanced driving force along the pores, resulting in higher adsorption capacity [32]. However, Xiao et al. have shown that the effect of concentration is lower [13]. The contact time affects the adsorption capacity as well. From the current study, the effects of driving force and mass transfer are minimal in the dynamic adsorption. Moreover, it is limited by the rate of molecular diffusion into deeper pores and the adsorption process. The percentage of removal of $\mathrm{H}_{2} \mathrm{~S}$ is $43 \%$, which is calculated using equation 15 below:

$$
\text { Removal }(\%)=\frac{C_{0}-C_{e}}{C_{0}} \times 100
$$

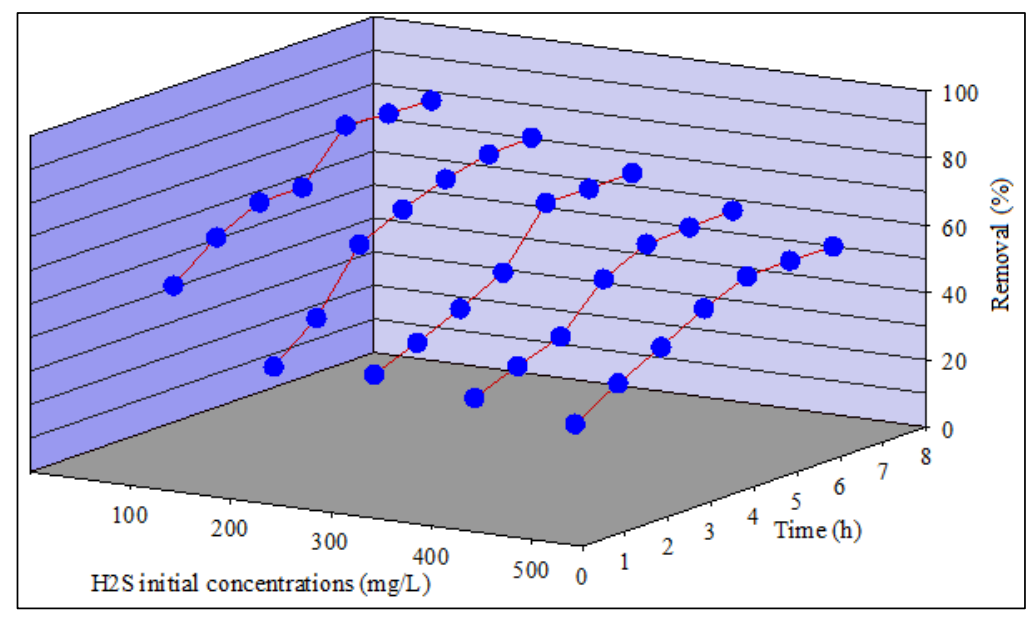

Figure 4. Effect of agitation time on $\mathrm{H}_{2} \mathrm{~S}$ adsorption onto ACES at various initial concentrations $(100-500 \mathrm{mg} / \mathrm{L})$

\section{Adsorption isotherms}

The adsorption isotherm demonstrates the adsorption process when it reaches an equilibrium state. It reveals on how the adsorption molecules are distributed between the solid phase and the liquid phase. The analysis of the isotherm data, which is performed by fitting the data on different isotherm models, is an important step to find the suitable model that can be used for design purposes [33]. Basically, adsorption isotherm is important to describe how solutes interact with adsorbents, and is critical in optimizing the use of adsorbents. $R^{2}$ value is used to identify the appropriate model of the adsorption process. Figure 5 shows the Langmuir isotherm model, where $1 / q_{\mathrm{e}}$ changes linearly with $1 / C_{\mathrm{e}}$, at a slope of $1 / Q_{\mathrm{o}}$ b. The Langmuir constants $b$ and $Q_{\mathrm{o}}$ are shown in Table $3 . R^{2}$ is 0.9849 , indicating that the fitting error is quite high compare with Freundlich isotherm model. To support that, the essential characteristics of the Langmuir isotherm can be expressed in terms of a dimensionless equilibrium parameter $\left(R_{\mathrm{L}}\right)$, 
Habeeb et al: ISOTHERMAL MODELLING BASED EXPERIMENTAL STUDY OF DISSOLVED HYDROGEN SULFIDE ADSORPTION FROM WASTE WATER USING EGGSHELL BASED ACTIVATED CARBON

and the value of $R_{\mathrm{L}}$ is 0.069 . Indeed, this indicates that the Langmuir isotherm is favorable for the adsorption of $\mathrm{H}_{2} \mathrm{~S}$ by the ACES under the working conditions considered in this study.

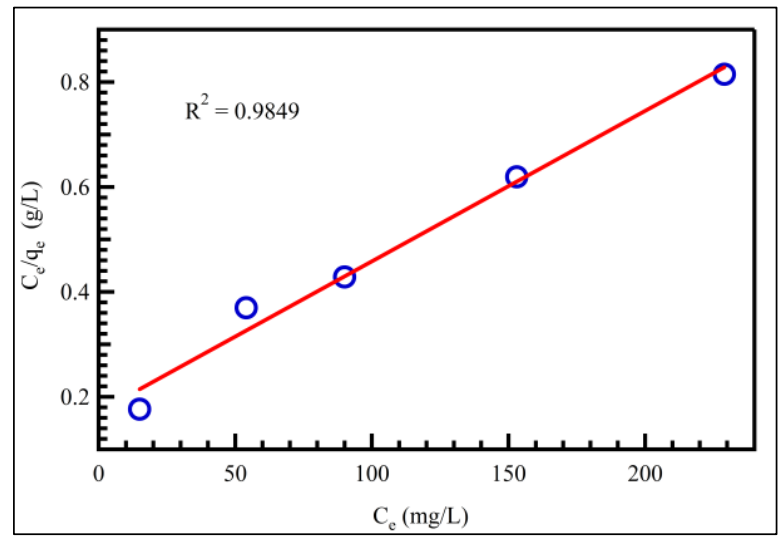

Figure 5. Langmuir adsorption isotherm of $\mathrm{H}_{2} \mathrm{~S}$ adsorption onto ACES

Table 3. Parameters of Langmuir and Freundlich adsorption isotherm models of $\mathrm{H}_{2} \mathrm{~S}$ adsorption onto ACES

\begin{tabular}{cccccc}
\hline Langmuir & \multicolumn{5}{c}{ Freundlich } \\
\hline$Q_{\max }(\mathrm{mg} / \mathrm{g})$ & $\mathrm{K}_{\mathrm{L}}(\mathrm{L} / \mathrm{mg})$ & $\mathrm{R}^{2}$ & $\mathrm{~K}_{\mathrm{F}}\left(\mathrm{mg} / \mathrm{g}(\mathrm{L} / \mathrm{mg})^{1 / \mathrm{n}}\right)$ & $1 / \mathrm{n}$ & $\mathrm{R}^{2}$ \\
289.3 & 0.02704 & 0.9849 & 25.16 & 0.452 & 0.9874 \\
\hline
\end{tabular}

According to Freundlich isotherm plot $\left(\log q_{\mathrm{e}}\right.$ vs. $\left.\log C_{\mathrm{e}}\right), 1 / n$ of 0.452 could be obtained from the slope the straight line gives as shown in Figure 6, showing that the adsorption of $\mathrm{H}_{2} \mathrm{~S}$ on the ACES is favorable. Accordingly, the Freundlich constants $K_{\mathrm{F}}$ and $n$ are reported in Table 3. $R^{2}$ is 0.9874 , indicating that the fitting error is lower than that of the Langmuir model. Table 4 compares the adsorption capacities of various adsorbents. It is interesting to see that the ACES has the highest adsorption capacity as compared to other adsorbents reported in the literature.

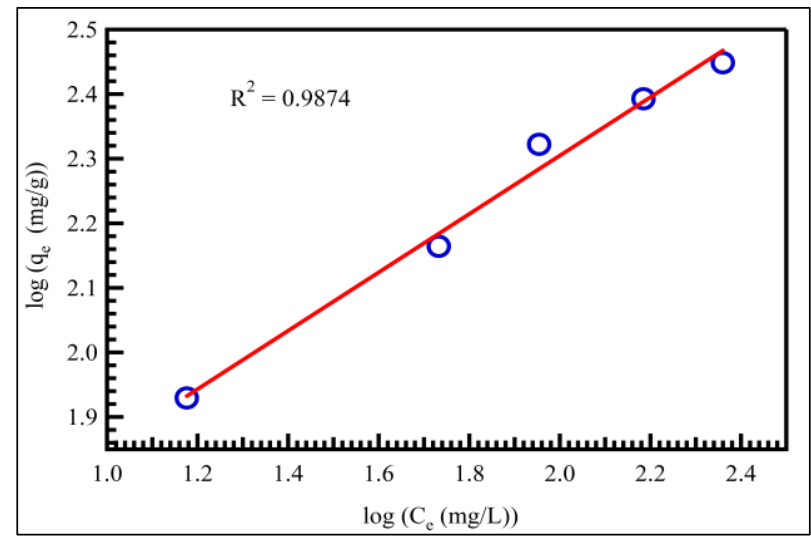

Figure 6. Freundlich adsorption isotherm of $\mathrm{H}_{2} \mathrm{~S}$ adsorption onto ACES 
Table 4. Comparison of maximum monolayer adsorption capacity of dissolved $\mathrm{H}_{2} \mathrm{~S}$ on various adsorbents

\begin{tabular}{llcl}
\hline Adsorbent & Adsorbate & $\begin{array}{c}\text { Adsorption Capacity } \\
(\mathrm{mg} / \mathrm{g})\end{array}$ & References \\
\hline Carbon derived from eggshells & $\mathrm{H}_{2} \mathrm{~S}$ & 289.3 & This work \\
IAC under anaerobic conditions & $\mathrm{H}_{2} \mathrm{~S}$ & 9.4 & {$[34]$} \\
Fine rubber particle media & $\mathrm{H}_{2} \mathrm{~S}$ & 0.12 & {$[17]$} \\
Crushed oyster shell & $\mathrm{H}_{2} \mathrm{~S}$ & 12 & {$[18]$} \\
Red mud & $\mathrm{H}_{2} \mathrm{~S}$ & 17 & {$[35]$} \\
Carbonated steel slag & $\mathrm{H}_{2} \mathrm{~S}$ & 7.5 & {$[36]$} \\
Activated carbon from sawdust pellets & $\mathrm{H}_{2} \mathrm{~S}$ & 6.2 & {$[37]$} \\
\hline
\end{tabular}

\section{Adsorption kinetics}

The relation between $\log \left(\mathrm{q}_{\mathrm{e}}-\mathrm{q}_{\mathrm{t}}\right)$ and time showed straight lines as displayed in Figure $7 \mathrm{a}$ for the pseudo-first-order kinetic model. $\mathrm{R}^{2}$ and $\mathrm{k}_{1}$ values are listed in Table 5. On the other hand, linear relationships were obtained by plotting $t / q_{t}$ versus $t$ (Figure $7 b$ ) for the pseudo-second-order kinetic model. Moreover, the $q_{e}$ and $k_{2}$ were determined from the slope and the intercept of the plot and listed in Table 5.

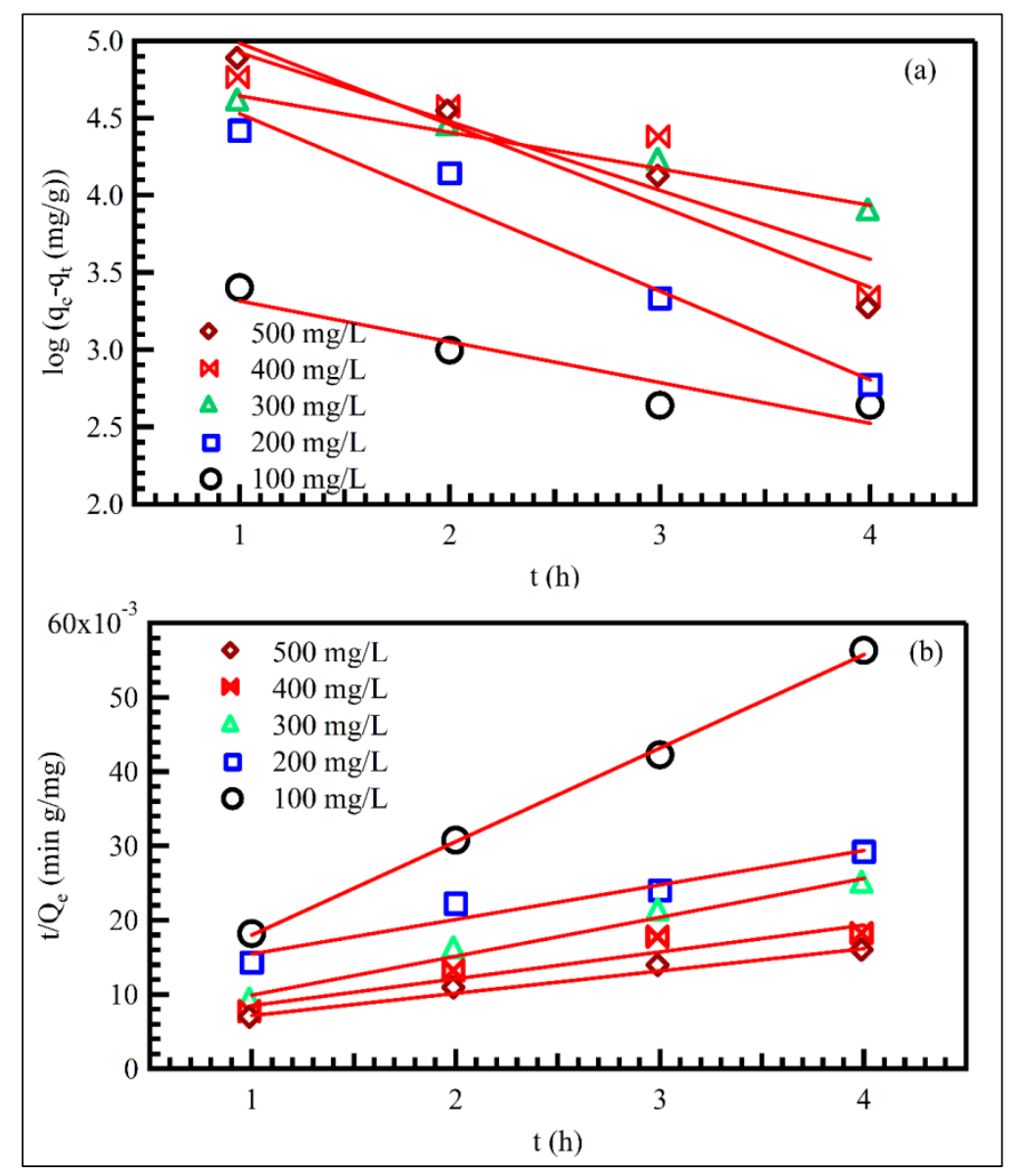

Figure 7. Pseudo-first-order (a) and pseudo-second-order (b) models of $\mathrm{H}_{2} \mathrm{~S}$ adsorption onto ACES 
Habeeb et al: ISOTHERMAL MODELLING BASED EXPERIMENTAL STUDY OF DISSOLVED HYDROGEN SULFIDE ADSORPTION FROM WASTE WATER USING EGGSHELL BASED ACTIVATED CARBON

Table 5. Pseudo-first-order and pseudo-second-order kinetic models' parameters for adsorption of $\mathrm{H}_{2} \mathrm{~S}$ onto ACES

\begin{tabular}{lllllll}
\hline \multirow{2}{*}{ Kinetic Model } & \multirow{2}{*}{ Parameter } & \multicolumn{6}{c}{ Initial $\mathbf{H}_{\mathbf{2}}$ S Concentration (mg/L) } \\
\cline { 3 - 7 } & & $\mathbf{1 0 0}$ & $\mathbf{2 0 0}$ & $\mathbf{3 0 0}$ & $\mathbf{4 0 0}$ & $\mathbf{5 0 0}$ \\
\hline \multirow{2}{*}{ Pseudo-first-order kinetic model } & $\mathrm{K}_{1}(1 / \mathrm{h})$ & 0.264 & 0.574 & 0.236 & 0.445 & 0.527 \\
& $\mathrm{R}^{2}$ & 0.884 & 0.970 & 0.820 & 0.950 & 0.970 \\
& $\mathrm{~K}_{2}(\mathrm{~g} / \mathrm{mg} \mathrm{h})$ & 0.024 & 0.002 & 0.005 & 0.002 & 0.002 \\
& $\mathrm{R}^{2}$ & 0.998 & 0.943 & 0.981 & 0.907 & 0.980 \\
\hline
\end{tabular}

This procedure is more likely to predict the behavior over the whole range of adsorption. It shows a good agreement between the experimental and the calculated $\mathrm{q}_{\mathrm{e}}$ values (Table 5). It is found that, the correlation coefficients for the second-order kinetic model were higher than those for the pseudo-first-order model, indicating the applicability of the second-order kinetic model to describe the adsorption process of $\mathrm{H}_{2} \mathrm{~S}$ onto the prepared ACES $\mathrm{R}^{2}$ values obtained are shown in Table 5 and they are low compared to those obtained from pseudo-second-order. Table 5 lists the calculated parameters and it is found that the adsorption of $\mathrm{H}_{2} \mathrm{~S}$ on ACES could be best described by the secondorder kinetic model.

\section{Conclusion}

The activated carbons have been prepared and analyzed to characterize their physical and chemical properties. The resulting solid samples have been used in the adsorption process of dissolved hydrogen sulfide from aqueous solution. From the current study, the activated carbon derived from the eggshell has the maximum adsorption capacity of $289.3 \mathrm{mg} / \mathrm{g}$ which is the highest amongst the other adsorbents reported earlier. The result indicate also that the initial concentration has an important role in the adsorption capacity. The adsorption isotherm fit very well to the well-known Freundlich isotherm model. In addition, the process followed the pseudo-second-order kinetic model. Thus, it can be concluded that eggshell is a very useful green and economic adsorbent due to its good accessibility and absence of any toxic and hazardous elements. Therefore, it is a very suitable candidate for removing $\mathrm{H}_{2} \mathrm{~S}$ from wastewater.

\section{Acknowledgement}

This work has been funded by Universiti Malaysia Pahang, Faculty of Chemical and Natural Resources Engineering, through a local research grant scheme (ERGS) No. RDU130618.

\section{References}

1. Patnaik, P. (2013). Handbook of inorganic chemicals. McGraw-Hill, New York.

2. Vollertsen, J., Nielsen, A. H., Jensen, H. S., Wium-Andersen, T. and Hvitved-Jacobsen, T. (2008). Corrosion of concrete sewers - the kinetics of hydrogen sulfide oxidation. Science of The Total Environment, 394(1): 162 170.

3. Agrahari, G. K., Rawat, A., Verma, N. and Bhattacharya, P. K. (2013). Removal of dissolved $\mathrm{H}_{2} \mathrm{~S}$ from wastewater using hollow fiber membrane contactor: Experimental and mathematical analysis. Desalination, 314: $34-42$.

4. Ma, H., Cheng, X., Li, G., Chen, S., Quan, Z., Zhao, S. and Niu, L. (2000). The influence of hydrogen sulfide on corrosion of iron under different conditions. Corrosion Science, 42(10): $1669-1683$.

5. Skrtic, L. (2006). Hydrogen sulfide, oil and gas, and people's health. Thesis Master, Universiti of California.

6. Lambert, T. W., Goodwin, V. M., Stefani, D. and Strosher, L. (2006). Hydrogen sulfide $\left(\mathrm{H}_{2} \mathrm{~S}\right)$ and sour gas effects on the eye. A historical perspective. Science of The Total Environment, 367(1): 1-22.

7. World Health Organization (2008). Guidelines for drinking-water quality: incorporating first and second addenda. WHO Press: pp. 185.

8. Hughes, M. N., Centelles, M. N. and Moore, K. P. (2009). Making and working with hydrogen sulfide: the chemistry and generation of hydrogen sulfide in vitro and its measurement in vivo: a review. Free Radical Biology and Medicine, 47(10): 1346 - 1353. 
9. Kularatne, K. I. A., Dissanayake, D. P. and Mahanama, K. R. R. (2003). Contribution of dissolved sulfates and sulfites in hydrogen sulfide emission from stagnant water bodies in Sri Lanka. Chemosphere, 52(5): 901 - 907.

10. Yongsiri, C., Vollertsen, J. and Hvitved-Jacobsen, T. (2004). Effect of temperature on air-water transfer of hydrogen sulfide. Journal of Environmental Engineering, 130(1): $104-109$.

11. Heinonen, A. (2012). Adsorption of hydrogen sulfide by modified cellulose nano/microcrystals. Master Thesis, Lappeenranta University of Technology.

12. Wesley Jr, E. W. (1980). Principles of water quality management. CBI Publishing Company Inc, Boston, USA.

13. Xiao, Y., Wang, S., Wu, D. and Yuan, Q. (2008). Experimental and simulation study of hydrogen sulfide adsorption on impregnated activated carbon under anaerobic conditions. Journal of Hazardous Materials, 153(3): $1193-1200$.

14. Yuan, W. and Bandosz, T. J. (2007). Removal of hydrogen sulfide from biogas on sludge-derived adsorbents. Fuel, 86(17): $2736-2746$.

15. Guo, J., Luo, Y., Lua, A. C., Chi, R. A., Chen, Y. L., Bao, X. T. and Xiang, S. X. (2007). Adsorption of hydrogen sulphide $\left(\mathrm{H}_{2} \mathrm{~S}\right)$ by activated carbons derived from oil-palm shell. Carbon, 45(2): 330 - 336.

16. Wang, C. and Pei, Y. (2012). The removal of hydrogen sulfide in solution by ferric and alum water treatment residuals. Chemosphere, 88(10): $1178-1183$.

17. Wang, N., Park, J. and Ellis, T. G. (2013). The mechanism of hydrogen sulfide adsorption on fine rubber particle media (FRPM). Journal of Hazardous Materials, 260: 921 - 928.

18. Asaoka, S., Yamamoto, T., Kondo, S. dan Hayakawa, S. (2009). Removal of hydrogen sulfide using crushed oyster shell from pore water to remediate organically enriched coastal marine sediments. Bioresource Technology, 100(18): $4127-4132$.

19. Poulton, S. W., Krom, M. D., Van Rijn, J. and Raiswell, R. (2002). The use of hydrous iron (III) oxides for the removal of hydrogen sulphide in aqueous systems. Water Research, 36(4): $825-834$.

20. Haddadian, Z., Shavandi, M. A., Abidin, Z. Z., Fakhru'l-Razi, A. and Ismail, M. H. S. (2013). Removal methyl orange from aqueous solutions using dragon fruit (Hylocereusundatus) foliage. Chemical Science Transactions, 2(3): $900-910$.

21. Yang, K., Peng, J., Srinivasakannan, C., Zhang, L., Xia, H. and Duan, X. (2010). Preparation of high surface area activated carbon from coconut shells using microwave heating. Bioresource Technology, 101(15): 6163 6169.

22. Martins, A. C., Pezoti, O., Cazetta, A. L., Bedin, K. C., Yamazaki, D. A., Bandoch, G. F., Asefa, T., Visentainer, J. V. and Almeida, V. C. (2015). Removal of tetracycline by $\mathrm{NaOH}$-activated carbon produced from macadamia nut shells: kinetic and equilibrium studies. Chemical Engineering Journal, 260: 291 - 299.

23. Farma, R., Deraman, M., Awitdrus, A., Talib, I. A., Taer, E., Basri, N. H., Manjunatha, J. G., Ishak, M. M., Dollah, B. N. M. and Hashmi, S. A. (2013). Preparation of highly porous binderless activated carbon electrodes from fibres of oil palm empty fruit bunches for application in supercapacitors. Bioresource Technology, 132: $254-261$.

24. Gao, P., Liu, Z. H., Xue, G., Han, B. and Zhou, M. H. (2011). Preparation and characterization of activated carbon produced from rice straw by $\left(\mathrm{NH}_{4}\right)_{2} \mathrm{HPO}_{4}$ activation. Bioresource Technology, 102(3): $3645-3648$.

25. Pundir, C. S., Bhambi, M. and Chauhan, N. S. (2009). Chemical activation of egg shell membrane for covalent immobilization of enzymes and its evaluation as inert support in urinary oxalate determination. Talanta, 77(5): $1688-1693$.

26. Giraldo, L. and Moreno-Piraján, J. C. (2014). Study of adsorption of phenol on activated carbons obtained from eggshells. Journal of Analytical and Applied Pyrolysis, 106: 41 - 47.

27. Silva, P. R., Ponte, H. A., Ponte, M. J. J. S. and Kaminari, N. M. S. (2011). Development of a new electrochemical methodology at carbon steel/Na2S system for corrosion monitoring in oil refineries. Journal of Applied Electrochemistry, 41(3): 317 - 320.

28. Weber, T. W. and Chakravorti, R. K. (1974). Pore and solid diffusion models for fixed-bed adsorbers. AIChE Journal, 20(2): $228-238$.

29. Weber, W. J. (1972). Physicochemical processes for water quality control. Wiley Interscience, New York: pp. 640.

30. Abdel Ghafar, H. H., Ali, G. A. M., Fouad, O. A. and Makhlouf, S. A. (2015). Enhancement of adsorption efficiency of methylene blue on $\mathrm{Co}_{3} \mathrm{O}_{4} / \mathrm{SiO}_{2}$ nanocomposite. Desalination and Water Treatment, 53(11), 2980 $-2989$. 
31. Agarwal, S., Sadegh, H., Monajjemi, M., Hamdy, A. S., Ali, G. A. M., Memar, A. O., Shahryarighoshekandi, R., Tyagi, I. and Gupta, V. K. (2016). Efficient removal of toxic bromothymol blue and methylene blue from wastewater by polyvinyl alcohol. Journal of Molecular Liquids, 218: 191 - 197.

32. Choo, H. S., Lau, L. C., Mohamed, A. R. and Lee, K. T. (2013). Hydrogen sulfide adsorption by alka-line impregnated coconut shell activated carbon. Journal of Engineering Science and Technology, 8: 741 - 753.

33. El-Geundi, M. S. (1991). Homogeneous surface diffusion model for the adsorption of basic dyestuffs onto natural clay in batch adsorbers. Adsorption Science \& Technology, 8(4): $217-225$.

34. Xiao, Y., Wang, S., Wu, D. and Yuan, Q. (2008). Catalytic oxidation of hydrogen sulfide over unmodified and impregnated activated carbon. Separation and Purification Technology, 59(3): 326 - 332.

35. Sahu, R. C., Patel, R., and Ray, B. C. (2011). Removal of hydrogen sulfide using red mud at ambient conditions. Fuel Processing Technology, 92(8): 1587 - 1592.

36. Asaoka, S., Okamura, H., Morisawa, R., Murakami, H., Fukushi, K., Okajima, T., Katayama, M., Inada, Y., Yogi, C. and Ohta, T. (2013). Removal of hydrogen sulfide using carbonated steel slag. Chemical Engineering Journal, 228: 843-849.

37. Kazmierczak-Razna, J., Gralak-Podemska, B., Nowicki, P. and Pietrzak, R. (2015). The use of microwave radiation for obtaining activated carbons from sawdust and their potential application in removal of $\mathrm{NO}_{2}$ and $\mathrm{H}_{2}$ S. Chemical Engineering Journal, 269: 352 - 358. 